ISSN 1896-4087

DOI: http://dx.doi.org/10.21784/ZC.2016.001

ANDRZEJ SEPKOWSKI

PWSZ we Włocławku

\title{
Zbawienie w demokracji
}

\section{Salvation in democracy}

\section{Streszczenie:}

Demokracja potrzebuje podejmowania działania bez nadmiernego uprzywilejowania status quo. Gdy indywidualny interes zaczyna dominować wywołuje to konflikt, zadaniem systemu demokratycznego jest wzmocnienie status quo, przez podejmowanie działań z wykorzystaniem siły lub groźby/ zmuszania/ niektórych swoich obywateli do sytuacji lub działań nie będących w ich interesie. Rząd w większości jest standardowym mechanizmem osiągania względnie zadowalającej formy demokratycznego przymusu.

W systemie demokratycznym można, niewątpliwie, rozstrzygnąć niektóre konflikty za pomocą narad, które mogą doprowadzić co przekształcenia interesów i ukazać niezrealizowane obszary. Może także zaostrzyć obszar konfliktów pomiędzy uczestnikami. W dobrej demokracji, zarówno w dużych jak i małych grupach, areny obrad winny być równo dostępne dla wszystkich i posiadać moc - także w sensie gróźb sankcji czy użycia siły wzmacniając lepszą argumentację, szczególnie w tych momentach kiedy w pewnych kwestiach nie dojdzie do porozumienia. Należy wskazać obszary, w których należy dążyć do porozumienia uczestników, którzy mogą przejawiać sprzeczne interesy. Należy tak prowadzić rozmowy, aby uczestnicy zrozumieli własne interesy, co jest szczególnie ważne w tych momentach kiedy jasne staje się, że interesy materialne, wartości głębokie uczestników, nie zawsze da się pogodzić z dobrem ogółu/innych uczestników. W tym momencie, gdy konflikt pozostaje po dobrej deliberacji, demokracja ma dwie 
możliwości - pozostać na status quo lub działać poprzez zmuszanie niektórych do tego aby iść razem z innymi.

Słowa kluczowe: demokracja, zbawienie, cywilna religia

\begin{abstract}
:
Democracies need coercion primarily to take action without overly privileging the status quo. When individual interests come in what gives every indication of being an irreconcilable conflict, a democratic polity must either reinforce the status quo by taking no action or by taking action, force or threaten/coerce/some of its citizens into situations or actions not in their interests. Majority rule is one standard mechanism for achieving a relatively fair form of democratic coercion. Democracies can undoubtedly settle some of many conflicts through deliberation. Deliberation can help transform interests ad reveal previously unrealized areas of agreement. It can also sharpen participants understandings of their conflicts. In a good democracy, large or small, the deliberative arena should ideally be equally open to all, and power - in the sense of threat of sanction or the use of force - should not interfere with the impact of the better argument. At some point and some issues, deliberation will not lead to agreement. Good deliberation will have opened areas of agreement and will have clarified and remaining areas of conflict. The participants will have come to understand their interests, including their conflicting interests, better than before deliberation. But material interests, and interests in one's deepest values, cannot always be reconciled with the interests, material and ideal, of others. At this point, when conflict remains after good deliberation, a democracy has two choices - to remain at the status quo or to act, by coercing some to go along with others.
\end{abstract}

Keywords: democracy, salvation, civil religion 
Co miał na myśli prezydent F.D. Roosevelt powiadając: „Dajcie mi demokracji, jeszcze demokracji i jeszcze więcej demokracji”?. Naszym zdaniem nie myślał o jej formach, uznawanych już wtedy przez Amerykanów za najdoskonalsze na świecie, ale o treściach, zbawczych treściach demokracji, w Ameryce wszechobecnych, bo bodaj w żadnej demokracji nie mówi się tyle o wolności, równości, sprawiedliwości. Mówił to przecież w czasie, w którym Wielki Kryzys był także kryzysem nie form, ale treści. One jakby pozostają poza granicami refleksji zwłaszcza politologów, a przecież wiemy, zgadzamy się z Arystotelesem, że hyle nie może istnieć bez morfe i ta współzależność powinna nas inspirować przy poszukiwaniu i optymalnych form, i moderujących je, inspirujących treści demokracji. Jeśli zastanowimy się nad jej sprawczymi mocami, to powinniśmy dostrzec, że to nie formy nas do niej przekonują, a właśnie treści, bo formy, zwłaszcza w naszym czasie, raczej zniechęcają do niej i wiele wskazuje, że będą zniechęcały jeszcze bardziej. Te pierwsze bywają czasami kalekie, niekiedy karykaturalne, a jednak nie odwracamy się od niej, niekiedy wcale nie dlatego, że niczego lepszego jeszcze nie wymyślono, jak powiadał Churchill, chyba nie będący najlepszego zdania o ludzkim myśleniu. Obudowano te formy setkami mityzacji mającymi charakter prawdziwych świątyń i codziennie uświęcają je media².

Kiedy przyglądamy się dysputom o demokracji, czasami uderzają argumenty odwołujące się do emocji. Powiada się, jak D. Kaplan, że demokracja to: „Jeden z najrzadszych, najbardziej delikatnych i kruchych kwiatów w dżungli ludzkiego doświadczenia"3. Przyjmujemy takie metafory, poprzestając na utartych sądach, nie chcąc zastanawiać się nad jej istotą, chociaż jesteśmy jej beneficjentami i chyba po-

\footnotetext{
${ }^{1}$ H. W. Mc Coil, The History of Liberty, New York 1965, s. 48.

2 W. L. Bennet, The Politics of Illusion, Washington 1996, s. 193.

${ }^{3}$ Cyt. za: D. R. Hiley, Doubt and Demands of Democratic Citizenship, Cambridge 2006, s. 5.
} 
winniśmy $\mathrm{w}$ trosce o nią samą, jeśli zauważamy, że w ponowoczesności jej formy zaczynają się po prostu degenerować, co owocuje ich kwestionowaniem przez wyborców. Takie symptomy utraty czystości form zauważał znakomity teoretyk, utrzymujący, iż w naszym czasie jest nam potrzebna idea idealnej demokracji i z tym można się godzić4.

A wymyślono „system polityczny posiadający konstytucyjne gwarancje możliwości regularnej zmiany osób u władzy oraz mechanizm społeczny zapewniający możliwie największej części ludności wpływ na podstawowe decyzje za pomocą wyboru spośród osób ubiegających się o stanowiska polityczne"5. Teoretyk, jak łatwo zauważyć, mówił tylko o formach, podobnie jak inny, wyliczający warunki demokracji, a są nimi: rzeczywiste uczestnictwo, równe prawo głosu, oświecone rozumienie, nadzór nad podejmowanymi zadaniami6. Jedynie owo enigmatyczne „oświecone rozumienie” zdaje się nieco, ale tylko nieco korespondować z treściami, choć nie wiemy, co naprawdę może znaczyć, zwłaszcza dla „mniej oświeconych”. Nadto, teoretyk nie zauważał tego, że każdy nadzór nad zadaniami był i jest czystą iluzją. Bez kompetentnych, sprawnych pośredników taki nadzór grupy społecznej jest niemożliwy, a nie uznajemy za formę nadzoru nacisków, choćby strajkowych, te są tylko próbami wymuszania korekt korzystnych dla jakiejś grupy decyzji politycznych. Inny zaś przyznawał, że zdefiniowanie demokracji jest niemożliwe, gdyż jest ona zbyt dynamiczna, nabiera różnych znaczeń w czasie ${ }^{7}$.

Po takiej konstatacji i lekturze jego wywodów można zrozumieć, dlaczego teoretyk uznał ją za niedefiniowalną, a za metaforę determinującą życie milionów. Powód był raczej prosty i nie wynikał z przekonania, że obdarzanie jej „pocałunkiem śmierci” (jak zwie się czasami definicje), nie jest pożądane. Autor zamierzył stworzyć panegiryk na

\footnotetext{
4 R. Dahl, On Political Equality, Yale University 2006, s. 6.

${ }^{5}$ S. M. Lipset, Homo politicus. Społeczne podstawy polityki, Warszawa 1998, s. 48.

${ }^{6}$ R. Dahl, $O$ demokracji, Kraków 2000, s. 39.

7 G. Sorensen, Democracy and Democratization, Oxford 1993, s. 23.
} 
cześć jej form, nie dostrzegając w ogóle treści, a nie wspominamy o tym, że przyznając niemożność jej zdefiniowana, nie powinien zajmować się nią w ogóle. Ale gdyby je zauważył, podówczas musiałby chyba przyznać, że jej dynamika to tylko sztafaż, tylko pozory mające przekonywać innych wyznawców do powtarzania demokratycznego credo. Demokracja rzekomo jest najlepszym w dziejach rozjemcą między jednostką a społeczeństwem, z którym pozostaje w odwiecznym konflikcie, ale takie sugestie zdają się prostymi nadużyciami, bo wydaje się, że inne formy władzy skuteczniej zapobiegają takim konfliktom, a demokracja, umożliwiająca artykułowanie tysięcy interesów jednostkowych i grupowych, jest jednak z natury bardziej konfliktogenna, choć konflikty mają z pewnością łagodniejszy charakter, w jakiejś mierze dzięki temu, że społeczeństwa demokratyczne są spełnione materialnie i swoje umiarkowane niezadowolenie wyrażają $\mathrm{w}$ formach łagodnych, jak Niemcy po reformach kanclerza G. Schroedera i A. Merkel. Ale brak zaufania do demokratycznego państwa nie dbającego o reformy socjalne może przynieść więcej epizodów podobnych do pamiętnych starć młodzieży z policją w Helligendamm.

Podobne takiej jak Lipseta definicje klasyków politologii prezentują się czasami jak prawdziwe „pocałunki śmierci”, ale są tak suche, że nie mówią nam właściwie nic o istocie demokracji, o ideach, które są pierwotne wobec form. Definicje, które nazywamy wyznawczymi, brzmią jak święte przykazania nakazujące bezkrytyczną wiarę w dogmaty, które nimi nie są, bo trudno tak traktować formy będące tylko mglistą emanacją dogmatów i takie pojmowanie form wygląda jak idolatria, a rytualizatorzy stosują praktyki podobne do tych, jakimi książęta Kościoła traktowali herezjarchów. Mamy z nimi do czynienia niemal na co dzień i czasami można myśleć jak P. Philips, powiadający, że czasami propaganda działa o wiele skuteczniej na jej twórców niż odbiorców ${ }^{8}$. Ale nietrudno zauważyć, że elastyczne i praktyczne zarazem formy okazywały się niezwykle funkcjonalne w nowocze-

8 P. Philips, Media Democracy in Action, Censored 2004, New York 2003, s. 297. 
sności i to przesądzało o trwałości i popularności demokracji jako symbolu ustroju bliskiego pełni.

Nie sposób także nie dostrzegać tego, co noblista, zauważający, że mimo wszystko demokracja zapewnia tę elastyczność polityki ekonomicznej i adekwatność działań publicznych w sytuacji kryzysów społecznych ${ }^{9}$. Wedle niego państwa demokratyczne nie znają głodu, krańcowego ubóstwa i zawdzięczają to właśnie tej zbawczej sile. Nie bardzo godzi się to z praktyką młodych europejskich demokracji XIX wieku, pełnych wstydliwej nędzy, ale nie da się ukryć, że treści demokracji niejako wymuszały stałą poprawę bytu obywateli i to w dwojaki sposób. Z jednej strony były to działania misyjnych polityków, a z drugiej wymuszenia kultywujących te treści obywateli, rewolucjonizujących się, buntujących, strajkujących. Formy demokracji mogą wymuszać to, do czego nie są zdolni kapitaliści, którzy zapewniali sobie dzięki nim spokój.

Podobny mit rytualizuje inny badacz, powiadający, że szerzenie się demokracji i kapitalizmu redukuje problemy globalne ${ }^{10}$. Taki sąd jest częściowo potwierdzony praktyką „starych demokracji”, ale sugestie, że formy mogą stawać się siłami sprawczymi zmian na lepsze w krajach zacofanych, rolniczych, są już zwykłą przesadą, a z taką możemy zetknąć się u natchnionych krzewicieli takich form w Afganistanie, Iraku. „Demokracja tu? - dziwił się analityk - ci ludzie tego nie rozumieją"11. Politycy amerykańscy także zdają się tego nie rozumieć, mimo, że teoretycy wielokrotnie zauważali, że żaden typ rządu nie jest odpowiedni do wszystkich warunków ${ }^{12}$. Powinni zrozumieć to ci misjonarze, którzy przecież od lat zauważają bliski mariaż demokracji z kapitalizmem, a Irak kapitalizmu nie doświadczał. Z pewnością Irakijczycy mają swoje poczucie wartości archetypicznych, ale od wie-

\footnotetext{
${ }^{9}$ A. Sen, Rozwój i wolność, Poznań 2002, s. 58.

10 J. Norberg, Spór o globalizację. Kto zyskuje, a kto traci, ile i dlaczego, Warszawa 2006, s. 64.

${ }^{11} \mathrm{~J}$. Ashcroft, Making a Killing, London 2006, s. 88.

12 C. G. Ryn, Democracy and the Ethical Life, London 1979, s. 16.
} 
ków ich wolność, równość i sprawiedliwość odnajdywały się w innych formach i narzucenie im innej formy wiary rzeczywiście jest krucjatą.

Z pewnością demokracja treści zapewnia homeostazę, ułatwia kompromisy między porządkiem, jaki jest niezbędny do funkcjonowania społeczeństwa ludzkiego, a zachowaniem takiej swobody działania jednostki, która stanowi jedno z jej ludzkich praw, warowanych kodeksami w „państwie prawa”, a to jeszcze jeden z mitów, tak brutalnie potraktowany przez Sartoriego. Solą demokracji jest kompromis, będący w dużej mierze jakby esencją treści, bo istota kompromisu wynika z wartości takich jak równość i sprawiedliwość13. Ale te kompromisy antagonistycznych zasad - zauważał teoretyk - prowadzą do tego, że zasady znoszą się, przestają być zasadami ${ }^{14}$. Choćby w przypadku Polski kompromis z jedną grupą społeczną oznacza pogorszenie statusów innych i tu przykłady możemy mnożyć. Można pokusić się o sugestię, że takie kompromisy, mające często charakter „zgniłych”, oznaczają nie tylko erozję wartości, ale także wiary w zbawienie przez demokrację.

Budowana na wartościach oświeceniowych zakładała także pryncypializm etyczny podbudowywany zaufaniem i tolerancją. Taki pryncypializm miał oznaczać tożsamość słowa i czynu, wiarę w słowa demokratycznych polityków, deklarujących zresztą takie postawy na co dzień i na co dzień je łamiących. Powiada się, że wiara w słowa jest jak puls demokracji, a szczególnie na to uczuleni są Amerykanie powtarzający z emfazą, że wszystko, co razi amerykańską wiarygodność, razi Amerykę ${ }^{15}$. Sarkastyczne komentarze do takich manifestacji wiary zdają się zbyteczne. Demokratyczni politycy, zwłaszcza w naszym czasie, zdają się pogrążać w klasycznym sytuacjonizmie etycznym i trzeba naprawdę głębokiej wiary, by poważnie traktować ich

13 J. Habermas, Democratic Theory, [w:] Democracy and Difference, S. Benhabib (red.), Princeton 1996, s. 26.

14 R. A. Dahl, A Preface to Democratic Theory, Chicago 1956, s. 4.

15 K. Hall. K. K. Jamieson, P. Campbell, The Interplay of Influence, Belmont 2001, s. 153 . 
deklaracje. Czy tego chcemy, czy nie, taki sytuacjonizm oznacza kryzys form demokracji, a ponieważ jest to stały, wznoszący się trend, możemy go ekstrapolować, sugerując, że będzie się pogłębiał i zbawcze role poczną zanikać.

Jeśli przyjrzymy się pracom teoretyków poszukujących korzeni demokracji w dziejach człowieka, bez trudu zauważymy niezwykłą, generującą moc wielkich archetypów mitycznych z mitami wolności, równości i sprawiedliwości na czele, bo to one stanowią podstawy demokratycznego porządku ${ }^{16}$. One właśnie są tymi treściami obudowywanymi dziesiątkami mityzacji. Poszukiwanie ich ziemskich hipostaz w nadziei na znalezienie ideału spełnienia od wieków było motorem rozwoju docenianym tylko przez niewielu, którzy dostrzegali generujące role czynników „historii nieświadomej” od K. Poppera poczynając. Te poszukiwania w ideach i praktyce codziennej są dla filozofa zarazem poszukiwaniami „życia świętego”, wypełnionego mocą, innego od codziennej szarości ${ }^{17}$. Te mity przyciągają, obezwładniają człowieka chcącego spełnić się w zbiorowości, w wartościach, a wydaje się, że jest potrzebą każdej jednostki, zawoalowaną, czasami maskowaną, ale rzeczywistą, nawet dla człowieka podwójnie zewnątrzsterownego, nie powodującego się własnymi doświadczeniami, a tylko takimi, jakie otrzymuje z zewnętrz. Człowiek spełnia się w formach, jakie są konsekwencją wyborów zbiorowości i jedną z takich jest demokracja.

Dla J. Pennocka, potwierdzającego rozumienie treści demokracji, swoistym eksperymentem w skali wieków jest wykorzystanie koagulatu wiecznych mitów tworzących podstawy demokratycznego credo $^{18}$. Autor ma swoje racje. Demokracja jest konstrukcją mityczną, ale nie nową, jak się czasami sugeruje $\mathrm{z}$ uporem godnym lepszej sprawy. Naszym zdaniem, a częściowo potwierdzają to teoretycy po-

\footnotetext{
16 J. M. Morone, Democratic Wish. Popular participation and the Limits of American Government, New York 19990, s. 23.

17 G. van der Leuw, Fenomenologia religii, Warszawa 1997, s. 177.

18 J. R. Pennock, Democratic Political Theory, Princeton University 1979, s. 16.
} 
szukujący dla niej szlachetnych genealogii, nie jest to eksperyment ostatnich wieków, ale proces transferu generujących idei, który zaczął się chyba wraz z wielkimi rewelacjami mitów fundamentalnych w kulturach pierwotnych, a one, wraz z idealizacjami wolności, równości i sprawiedliwości, pojawiały się przecież w mitologiach starożytnych, od krainy wiecznego szczęścia Dilmun w mitologii sumeryjskiej poczynając, a kończąc na wynaturzeniach XX wieku, bo przecież idee wolności i sprawiedliwości doskonałej były fundamentalne dla socjalistów, komunistów, faszystów ${ }^{19}$. Jakimś tego poświadczeniem jest poszukiwanie bohaterów walczących o wolność i równość w starożytności, że wspomnimy tu Kleomenesa, Agisa, Spartakusa, będących także herosami dla wszystkich uciśnionych.

Naszym zdaniem człowiek zbiorowy przez tysiąclecia poszukiwał form dla tych treści tak mocno utwierdzonych w społecznej immanencji, że nie udało się wykorzenić ich ani w niewolnictwie, ani w okresie feudalizmu. Być może, twierdząc, że idea demokracji poszukiwała dla siebie nowych miejsc i form, zbliżamy się do „wulgarnej” postaci kumulatywnego postępu, ale takie refleksje, takie wnioski nasuwają się nieodparcie. Demokracja i jej treści wyrastały z pnia mitycznego, ulegając wielu mutacjom w czasie, jakby dojrzewając, poszukując coraz pełniejszych postaci. Sprowadzanie jej tylko do form i procedur nie jest zasadne i nie może przynieść efektów w praktyce uważał V. Possenti20. Za tym muszą iść konkretne, namacalne potwierdzenia wiary w treści, a nie czysta kosmetyka. Modyfikacje form, takie jak idea demokracji deliberatywnej, tylko na jakiś czas dodają jej atrakcyjności, budzą ożywione dysputy intelektualistów i naukowców, chyba niewarte zachodu, skoro nie ma to żadnego przełożenia na praktykę i raczej mieć nie będzie. Weryfikacja tej nowej formy w praktyce społecznej już zdaje się dowodzić, że ten ekspery-

${ }^{19}$ A. J. Schmidt, Under the Influence. How Christianity transformed Civilization, Grand Rapids 2001, s. 258.

${ }^{20}$ V. Possenti, Religia i życie publiczne. Chrześcijaństwo $w$ dobie ponowożytnej, Warszawa 2005, s. 137. 
ment zakończył się niepowodzeniem, ale to sprawa drugoplanowa, twórcom tego modelu udało się potwierdzić, że demokracja ewoluuje, cały czas poszukuje swojej pełni, ale pełni przede wszystkim formalnej, a takie poszukiwania zmierzają do czynienia z niej zdumiewającego spektaklu. Podobnym potwierdzeniem jest mityzowany libertarianizm, przywracający do życia prawa człowieka do indywidualnego wyboru drogi życia czy obowiązek poszanowania praw innych ${ }^{21}$. Ma tylko urok nowości, jest przeznaczony dla konsumentów McFaktów, nic więcej.

Po to, by wzmocnić sugestie wiążące demokrację z wiecznymi archetypami, odwołamy się do autorytetów. Demokracja w jej treściach zdawała się być konstruktem mitycznym dla J. Deweya, który powiadał, że demokracja to coś więcej niż forma rządu, dużo więcej niż system emanacji władzy przez wybory. Demokracja to dla niego jedność, zbiorowa droga życia oparta na demokratycznym duchu, to wiara, „która musi zostać wyartykułowana i jest wielkim wyzwaniem dla filozofii22. Dewey nie był pierwszym, bo przed nim W. James powiadał, że demokracja jest rodzajem religii, świeckiej wiary i w imię wolności i równości jesteśmy zobowiązani do zapobiegania jej upadkowi ${ }^{23}$.R. Conquest zaś utrzymuje, że to, co nazywamy „demokracją” jest w znacznie mniejszym stopniu kwestią instytucji, a w znacznie większym kwestią nawyków psychicznych ${ }^{24}$.

Co mają oznaczać te nawyki nie bardzo wiemy i w tym przypadku uwaga wybitnego filozofa jest także tłumaczeniem nieznanego przez nieznane. Nie wiemy także, o czym myślał inny uczony, twierdząc: „Jeśli obywatele nie doświadczają demokracji jako realności, to ona nią nie jest"25. Co jest realnością demokracji? Raczej nie obowiązki

\footnotetext{
${ }^{21}$ D. Boaz, Libertarianizm, Poznań 2005, s. 12.

${ }^{22}$ Cyt. za: M. Kilanowski, Individual and Community, [w:] Deconstruction and Reconstruction, J. Ryder, M. Wilkanowski (red.). Amsterdam 2004, s. 29.

${ }^{23}$ J. Herring, The Politics of Democracy. American Parties in Action, New York 1968, s. 25.

24 R. Conquest, Uwagi o spustoszonym stuleciu, Warszawa 2001, s. 37.

25 J. C. Goldfarb, The Cynical Society. The Culture of Politics and the Politics of Culture in American Life, Chicago 1991, s. 197.
} 
obywatelskie, jakie często przyjmuje się jak balast, a realizacja jej zbawczych treści tylko częściowo potwierdzanych demokratycznym prawem. Zaufanie $\mathrm{w}$ jej formy rośnie, jeśli zwykli obywatele przekonują się, że równość i sprawiedliwość są zasadami niewzruszonymi, a chyba nie znajdziemy takich demokracji, które zapewniają takie, realizowane wartości blisko ich pełni. Setki potwierdzeń odchodzenia od zasad odnajdziemy przede wszystkim w kulturze masowej, setkach filmów, w których bycie politykiem demokratycznym oznacza bycie amoralnym, bezwzględnym draniem mającym na uwadze tylko swoje dobro. A poza tym one nie są do zrealizowania i nie będą dopóty, dopóki nie stworzymy ich idealnych modeli zaakceptowanych przez społeczności, a raczej nie stworzymy. Te pojęcia są naznaczone „nieusuwalną niejednoznacznością" - twierdził teoretyk ${ }^{26}$.

Naukowe i moralne autorytety uprawniały instrumentalne traktowanie mitów założycielskich, wskazywały drogi rytualizacji i w jakiejś mierze dzięki takiemu traktowaniu nie próbuje się kwestionować wiary w demokrację, jej wartości. Możemy nawet zauważyć przejawy prawdziwej idolatrii, bo dziś podejrzenie o antydemokratyzm - zauważał ze sporą przesadą jeden $\mathrm{z}$ autorów - ma taką samą moc, jak kiedyś podejrzenie o antychrześcijaństwo ${ }^{27}$. Chyba nie jest aż tak źle, bo dziś jak dogmat traktuje się twierdzenie, że „żadna demokracja nie może przeżyć, jeśli ludzie nie dzielą fundamentalnych wierzeń"28. I traktują go tak zwykli ludzie manifestujący swoją wiarę. Inną sprawą jest to, że wielu trzeźwych teoretyków naszego czasu zaczęło kwestionować formy demokracji i nie dość, że nie są traktowani jak herezjarchowie, to jeszcze spotykają się z uznaniem środowisk choćby naukowych, choć ich herezje nie docierają do większości wyznawców.

Jeśli potraktujemy demokrację jako postać wiary, a demokratyczne postawy i zachowania jako postaci swoistej religijności, to powinniśmy także przyjmować, iż dogmaty tej wiary nie mogą zostać naru-

\footnotetext{
26 H. Brighthouse, Sprawiedliwość, Warszawa 2007, s. 12.

27 J. Zadencki, Wobec despotyzmu wolności, Kraków 1995, s. 173.

28 B. Ginsberg, T. J. Lowi, M. Weir, We the People, New York 1997, s. 192.
} 
szone, bo każda próba podważenia jednego byłaby zarazem podważeniem całego gmachu wiary, że muszą istnieć jakieś sposoby przejawiania się tej religijności, czyli manifestowanie postaw i zachowań i, podobnie jak w teologii, gdzie zażarcie dyskutuje się imponderabilia, w demokracji także powinniśmy stale reprodukować i rewitalizować idee przez niekończący się dialog, bo same idee zmieniają się wraz ze światem społecznym i choćby nasze poczucie sprawiedliwości z dnia na dzień staje się inne. Idee demokracji są żywe, otwarte, ale tylko jako mutacje refleksji nad fundamentami mitycznymi, których nie można kwestionować. A demokratyczni politycy powinni pamiętać o tym, że kapitał polityczny, jaki zdobywają dzięki mechanicznej rytualizacji treści demokracji, wymaga stałego odtwarzania, bo on nie da się deponować i jest to swoista dyrektywa przestrzegania mitów demokracji jako żywych, które trzeba stale pielęgnować, nie ograniczając się do ich podziwiania, co zdaje się być codzienną praktyką tzw. „młodych demokracji”.

Muszą nie tylko deklarować, że chcą poszerzenia zakresów wolności, równości i sprawiedliwości, ale i potwierdzać takie chęci praktyką. Na naszym gruncie przez jakiś czas dobrze rozumieli to liderzy PiS orientujący się na sprawiedliwość i dzięki temu zdobywający władzę. Zapewne wiedzieli o tym, że nie zdołają zwiększyć przestrzeni wolności czy równości i obrócili się w stronę mitycznej sprawiedliwości, najtrudniejszej w konfrontacjach typu idealistycznego. Inną już było sprawą to, że nie potrafili przekonać swoją praktyką do zwiększania tych przestrzeni i ta kulawa praktyka obróciła się przeciwko nim. Wszyscy politycy muszą także pamiętać o tym, że tworzenie i rytualizacja nowych mitów tyczących form w demokracji może czynić z niej karykaturę. Tak jest w tych młodych demokracjach, gdzie wygrane wybory z poparciem nawet $10 \%$ społeczeństwa pozwalają na tworzenie iluzji mitycznej, że to naród oddał władzę wybrańcom. Tu pojawia się stare ostrzeżenie teoretyków powiadających, że w demokracji nie ma takiej większości, która byłaby przepustką do wszechwładzy. Jakość bliską wszechwładzy można zdobyć tylko wtedy, kiedy 
za obietnicami zbawienia w doczesności pójdą zdecydowane czyny tej władzy.

Siła mitu demokracji zdaje się być tak wielka jak niekonsekwencja człowieka mitycznego wobec własnego tworu, zdająca się pochodzić $\mathrm{z}$ inercji psychicznej, co dla teoretyka oznacza tendencję do sięgania po stare wzory, bo te są zwykle łatwiejsze w rozumieniu ${ }^{29}$. Intuicyjnie apologizując treści demokracji, obywatele akceptują formy niezagrażające $\mathrm{w}$ miarę pełnej realizacji tych treści, akceptując zarazem fundamentalne wierzenia. Ale dla tych, którzy osiągnęli zadowalające ich poziomy wolności, równości, mit demokracji jest wartością, choć ta wolność jest dziedzictwem nieco kłopotliwym, bo zmusza nas do zadawania nowych pytań ${ }^{30}$. Status materialny determinuje w ogromnym stopniu stosunek do niej i najzagorzalszymi wyznawcami demokratycznych mitów stają się ci, którzy już się zbawili albo ci, którzy mają nadzieje na zbawienie w niej, przez nią 31 .

Demokracja $\mathrm{z}$ definicji oznacza władzę należącą do ludzi, ale wtórna mityzacja czyni ją systemem, w którym ludzie mają prawo do głosowania, a to z pewnością nie jest to samo, choć tak często utożsamia się władzę z tym „prawem”. Demokracja ograniczona do tego prawa jest tylko systemem głosowania zamkniętym w procedurach ${ }^{32}$, a relacje między treściami a formami, które mogą czynić z niej jakość jedności form i treści, powinny wyglądać zdecydowanie inaczej, o ile nie jest możliwe sprowadzenie na ziemię zrealizowanych treści. Przynajmniej powinny zapewnić jednostkom wolność i równość w warunkach życiowego startu, a także równość obowiązków ${ }^{33}$. Takie odczucia miewają nawet politycy markujący wysiłki zmierzające do stworzenia

29 J. Conrad, Człowiek, rasa, kultura, Warszawa 1971, s. 124.

30 Z. Bauman, Wolność, Kraków 1995, s. 76.

31 R. A. Dahl, Dillemas of Pluralist Democracy, London 1982, s. 153.

32 C. G. Ryn, Democracy and the Ethical Life. A Philosophy of Politics and Community, London 1979, s. 3.

33 G. Sorensen, Democracy and Democratization. Dilemmas in World Politics, Boulder 1993, s. 10. 
takich warunków, ale w kulturze pozorów one mają moc działań magicznych.

Droga od tego „prawa” do realnej władzy jest zbyt długa dla przeciętnego, samozbawionego obywatela państwa demokratycznego, który chętnie zadowala się rolą obserwatora, nie uczestnika ${ }^{34}$, co nie znaczy, że przestał marzyć o byciu prawdziwym uczestnikiem, kreatorem. Zwłaszcza dziś, kiedy stylem dla większości wyznawców stała się medialna substytucja uczestnictwa w polityce. Nie przypadkiem demokracja jest tworem kapitalizmu i to społeczeństwo kapitalistyczne stworzyło system, w którym bogactwo ekonomiczne przekładało się na władzę polityczną ${ }^{35}$. Nie przypadkiem jej twórcy czynili ją systemem statusów społecznych w czasie, w którym umacniali polityczne i pozapolityczne struktury władzy pieniądza. Nie przypadkiem przez lata była luksusem dla bogatych. Powszechna w niej partycypacja stała się faktem dopiero wtedy, kiedy przekonano się, że przy pomocy wielu narzędzi można sterować preferencjami wyborczymi, przekonując zarazem, że jej formy są zgodne $\mathrm{z}$ wolą mitycznego „ludu".

Jak blisko jej z kapitalizmem, przekonywaliśmy się, śledząc jej rozwój w warunkach amerykańskich, w okresie „wieku pozłacanego”. Prawdziwi władcy uczynili słabe, demokratyczne państwo swoim narzędziem, nominalnie tylko zarządzanym przez prezydentów takich, jak A. Johnson, U. Grant, R.B. Hayes, Ch. A. Artur. Takie państwo było zbyt słabe nawet w roli „nocnego stróża”. Baronowie-rabusie byli jego prawdziwymi władcami, ale wtedy, kiedy pojawiła się konieczność powołania arbitra, rozjemcy, a także gwaranta udanych interesów na zewnątrz, zdecydowali się na wzmocnienie jego siły, ale, niejako wbrew nim, słowo „demokracja” stawało się głośniejsze we wznoszącym się crescendo ${ }^{36}$. Potrzebna była wiara, by spacyfikować tłum Le Bona, a masy są nieprzewidywalne, ich emocje mają niepojęte moce

\footnotetext{
34 N. Chomsky, Media Control, New York 2002, s. 17.

35 L. Thurow, Przyszłość kapitalizmu, Wrocław 1999, s. 328.

36 H. W. Mc Coil, The History of Liberty, New York 1965, s. 47.
} 
destrukcyjne. Demokracja dostarczyła źródeł emocji konstruktywnych i jej role w pacyfikacji nastrojów są bardzo dobrze widoczne. Chyba jej można zawdzięczać to, że tzw. „stare demokracje” uniknęły parkosyzmów rewolucyjnych po I wojnie światowej.

W takiej konkretnej sytuacji istnieje wiele przesłanek dla prostego wniosku, że demokracja jest tworem młodego kapitalizmu, jego symbiontem. Tworzono jej formy po to, by samoograniczała wilczy kapitalizm przez choćby łagodzenie form nieograniczonej konkurencji, tej tzw. wolnej gry sił. Twór kapitalizmu sam tworzył pozory ograniczenia twórcy i czynił to skutecznie. Wydaje się, że od samego początku jej treści widomie kłóciły się z kapitalizmem. Jak może wolność i równość pomieścić się w porządku kapitalistycznym? Tylko wówczas, kiedy demokracja zacznie dążyć do opanowania, etatyzacji gospodarki. Ale jeśli zacznie to czynić, podówczas pojawi się równość w biedzie, bo jednak kapitalizm mnoży bogactwa, choć rozdziela je nierówno. Demokracja oparta na etatyzmie byłaby tworem gorszym od jakiegokolwiek socjalizmu. Demokratyczni politycy dowodzili wiele razy, że są prawdziwymi wrogami gospodarki nie tylko za sprawą niekompetencji i takimi pozostaną dzięki woli tych, którzy dysponują prawdziwą władzą.

Poprzez samo głosowanie, przez wyrażenie swoich preferencji, jednostka nie jest w stanie wpływać na kształt polityki, nie czuje swojej części władzy ani tego, że sama pomaga sobie w spełnieniu. Zdaje sobie sprawę $\mathrm{z}$ tego, że wiara $\mathrm{w}$ ziszczenie idealnych treści powinna wymuszać działania dla jej doskonalenia, ale nawet nie jest w stanie wyartykułować konieczności odwołania reprezentantów, którzy sprzeniewierzyli się woli wyborcy. Ten wyznawca czasami wierzy w siebie jako cząstkę opinii publicznej, w zdolność do wymuszania decyzji na rządzących, ale ci, którzy racjonalizują swoje odczucia, są skłonni przychylać się do zdania J. Baudrillarda, powiadającego, że ta „opinia” to mityczna, opatrznościowa i suwerenna rzeczywistość 37 .

37 J. Baudrillard, Społeczeństwo konsumpcyjne, Warszawa 2004, s. 101. 
Opinię kształtują media, sugerując odbiorcom, że to emanacje ich emocji, przekonań, poglądów, wiary. One zaś są integralną częścią demokracji tworzącą pozory chęci bycia korektorem systemu, ale są także integralną częścią współczesnego systemu korporacyjnego ${ }^{38}$, co powinno podważać zaufanie do nich i kształtów tych „opinii”, jakie tworzą. Ze szczególną troską media dbają o to, by „opinia” była przychylna i demokracji, i kapitalizmowi w jego współczesnej postaci. Nietrudno choćby zauważyć, że media nie poświęcają wiele miejsca globalizacji w jej wielu odsłonach, unikając w ten sposób wielu pułapek.

Zauroczeni rytualizowanymi wytrwale przez media mitami demokracji nie jesteśmy w stanie zauważyć, że sama forma nie wystarcza, że mamy tu do czynienia z tym, co Ch. Handy nazwał symbolem pustego płaszcza ${ }^{39}$. Jego zdaniem, aby wypełnić ten płaszcz ludzką treścią, trzeba dać więcej władzy temu, co lokalne, małe. Mając na uwadze konstytuowanie się form demokracji amerykańskiej, chciał wracać do korzeni, zapominając jednak o tym, że żyjemy w postkapitalizmie i taka władza zależy od pieniędzy. Jego zdaniem właśnie tam można o wiele skuteczniej pomagać wspólnotom w realizacji ich małych celów. Naszym zaś zdaniem, pusty płaszcz można wypełnić tylko żywym ciałem wyborców, którzy, pamiętając o treściach, sami z siebie muszą ulepszać formy, na przykład wymuszać rezygnację prezydentów, gabinetów, których poparcie społeczne opada poniżej przyjętych granic. A poparcie spada nie dlatego, że wykoślawia się formy demokracji, ale dlatego, że wybrańcy zbyt mocno godzą w jej treści. To właśnie ci wybrańcy są powietrzem wypełniającym pusty płaszcz Handy'ego.

Od chwili jej narodzin problemem był wybór jednostek najlepszych, kompetentnych i altruistycznych, problemem sztucznym, bo mechanizmy selekcji $\mathrm{w}$ demokracji są nastawione na elastycznych,

38 E. S. Harman, R. W. Chesnay, The Global Media. The New Mission of Corporate Capitalism, London 1999, s. 10.

${ }^{39}$ Ch. Handy, Wiek paradoksu, Warszawa 1996, s. 97. 
posłusznych, interesownych polityków. Wybór najlepszych pozostawał swoistym imperatywem od czasów krytyki ochlokracji ateńskiej, imperatywem zmieniającym się w pobożne życzenia, które literalnie pojmowało niewielu polityków, jak choćby T. Roosevelt inspirujący zjawisko zwane muckrakingiem (demaskatorstwem). Próba stworzenia przy pomocy „demaskatorów” prawdziwie nowoczesnej elity władzy skończyła się niepowodzeniem, jak i większość podobnych wtedy, kiedy o kształtach elit przesądzali władcy pieniędzy. Powiada się, że one pozostały takimi, jakie są społeczeństwa, o ile jest nieco prawdy w sądzie, że wybrańcy są emanacją wyborców, w co raczej wątpimy. Prezydent Stanów zdawał się mieć za sobą lekturę Monteskiusza, który w „O duchu praw” pisał, że istnienie demokracji jest zagrożone, gdy zapomina się o tym, że choć każdy ma kwalifikacje po temu, by wybierać, to nie każdy po temu, by być wybranym. A jeśli tak, to demokracja pozostaje cały czas zagrożona. W wielu formach demokracji wybrańcy zdają się dobrze o tym wiedzieć, przynajmniej w Polsce. Zadbali o to, by ograniczyć ją do roli rytuału legitymizującego i reprodukującego klasę polityczną ${ }^{40}$, a dbając o swoje interesy, zdają się pewni tego, że nie wystąpią przeciw nim żadni herezjarchowie, bo ci zostaną natychmiast potępieni.

Takie zjawiska nie są właściwością polską, są powszechne, wspólne także „starym” demokracjom. Sama demokracja jest zjawiskiem zrodzonym na przełomie I i II fali, tworzono jej formy dla nowych, ekspansywnych grup społecznych i one stały się zbyt ciasne dla tych, którzy osiągnęli władzę polityczną po feudałach. Zdobyli swoje, wykorzystując treści demokracji, kreując odpowiednie dla nich formy. Ale po czasie, czując ciasnotę tego gorsetu, ograniczając formy z pozorami poszukiwania nowych, twórcy są zainteresowani jej dalszą limitacją. Gdzie indziej przywołamy argumenty przeciwników, tu zaś pozwolimy sobie przywołać autorytet sugerujący swego czasu (a czas jest ważny), że kapitalizm to spełnienie w polityce, bo tylko „kapita-

40 J. Staniszkis, Władza globalizacji, Warszawa 2003, s. 99. 
lizm tworzy warunki niezbędne dla politycznej wolności"41. Czyli dla demokracji, w której wolność jest filarem pierwszym. Jesteśmy jednak przekonani, że w naszym czasie trzeba będzie dopełnić powiedzenie Churchilla o tym, że demokracja nie jest czymś najlepszym, ale lepszego nie wymyślono. W naszym czasie czynienia z niej niezbyt wymyślnej karykatury chyba czas zacząć jednak wymyślać.

Takie punkty widzenia powinny zasługiwać na większą uwagę, ale nie wydaje się, by pojawili się organizatorzy wyobrażeń zbiorowych, którzy w naszym czasie wypełnią coraz bardziej pusty płaszcz. Przeszkodą pierwszą są strażnicy, depozytariusze klasycznego mitu demokracji przekonujący do wygodnych dla nich form, a mający wiele narzędzi perswazji. Przypomnijmy, że poza władzą polityczną (przymusu) i gospodarczą istnieje jeszcze niedoceniana władza symboliczna, której depozytariuszami są produkujący kapitał symboliczny i są to pisarze, dziennikarze, uczeni, ale użytek z tworzywa przez nich dostarczanego czynią właśnie politycy ${ }^{42}$. Dla jednego z badaczy władza symboliczna wywodzi się z działalności zmierzającej do produkowania, przekazywania i odbierania form symbolicznych będących nośnikami znaczenia ${ }^{43}$. Poznanie jej istoty jest tożsame z koniecznością pogłębionych, systematycznych badań nad kulturą symboliczną i powinniśmy zdawać sobie sprawę z tego, że ta kultura jest dla zbiorowości formą utrzymania spoistości, tożsamości - uważał D. Bell i zdaje się, że podobne przekonania ludzi nauki przełożyły się $\mathrm{w}$ jakiejś mierze na praktykę amerykańską ${ }^{4}$. Może okazać się przydatne w kreowaniu wizji zbawienia, jakich potrzebują społeczeństwa, a wybitny teoretyk miał na myśli stałą kultywację wyobrażeń zbiorowych ze szczególnym uwzględnieniem wartości.

Nietrudno zauważyć w enuncjacjach amerykańskich polityków tak częstych odwołań do treści demokracji, stałych rytualizacji symboli

\footnotetext{
41 M. Friedman, Capitalism and Freedom, Chicago 1982, s. 10.

42 T. A. van Dijk, Elite Discourse and Racism, Newbury Park 1993, s. 47.

43 J. B. Thompson, Media i nowoczesność. Społeczna teoria mediów, Wrocław 2001, s. 24 .

44 D. Bell, The Cultural Contradiction of Capitalism, London 1979, s. 36.
} 
i alegorii wolności, równości, sprawiedliwości. Oni zdają sobie sprawę z tego, że świat wyobrażeń zbiorowych trzeba kultywować stale, pieczołowicie pamiętając o tym, aby praktyka potwierdzała takie deklaracje. Tak było choćby z programem Reagana walki z nędzą. Oczywiście były to czcze deklaracje i po kilku latach pełnych działań pozorowanych, prezydent przyznał, że jednak ubóstwo zwyciężyło, co nie zaszkodziło jego popularności dzięki dziesiątkom działań pozorowanych - prawdziwej soli demokracji ${ }^{45}$. Na marginesie zauważmy, że nie wydaje się, by polscy politycy należycie rozumieli taką konieczność, choć można dostrzec, że czasami jednak pojmują ją empatycznie, wtedy zwłaszcza, kiedy przyparci do muru, rewitalizują stare symbole wielkiej triady, choć samą rytualizacją zwodzą zbiorowość tylko w krótkim czasie nadziei, nie mając zamiaru wspierać obietnic działaniami. Tworząc wizje, nie wiedzą o tym, że są to odpowiedzi na wyzwania i możliwości jutra, że zweryfikuje je przyszłośćc6.

Dysponujący władzą symboliczną mają niezwykłe możliwości kreowania nowych i rytualizacji starych mitów. Mają moc zmieniania całej przestrzeni mitycznej i czasami nie korzystają z niej z niewiedzy albo próbują korzystać tak, że działają na własną niekorzyść, nie zdając sobie sprawy z istoty tej władzy, podobnie jak wielu przedstawicieli tzw. „czwartej władzy”. Tymczasem, dysponując mediami, mogą korzenić i rytualizować nowe symbole pomni tego, że w ponowoczesności ludzie oswoili się z iluzyjnością poznania, przeżywania, zaakceptowali to, że teraz mapy rodzą nowe terytoria, choć to stwierdzenie J. Baudrillarda znakomicie przystaje do granic przestrzeni mitycznych tworzonych przez człowieka niejako „od zawsze"47. Dysponujący cząstkami władzy symbolicznej także „od zawsze” współtworzyli systemy wiary $\mathrm{w}$ wartości uniwersalne, obudowując je aksjonormatywnymi z ich zakazami i nakazami. Ale powtarzamy, że kreacje nowych

\footnotetext{
45 J. T. Patterson, America's Struggle Against Poverty, Harvard 1994, s. 224.

46 G. Hamel, C. K., Prahald Competing for the Future, Cambridge 1994, s. 74.

47 J. Baudrillard, Procesja symulakrów, [w:] Nowe media w komunikacji społecznej w XX wieku, M. Hopfinger (red.), Warszawa 2002, s. 629.
} 
„map" muszą iść w parze choćby z markowanymi intencjami poprawy bytu zbiorowości. Jeśli nie, podówczas wiara w nie zwątleje i społeczność poszukująca zbawienia zrezygnuje z pustych form demokracji i zawierzy innym. Tak było z demokratycznie wybranym kanclerzem Niemiec w 1933 roku. Przypomina się to często i chyba zasadnie.

Egzemplifikacją bastionu świata mitycznego jest jeden z filarów demokracji, czyli równość. Wiemy o tym, że odwieczny mit równości ma niebywałą moc sprawczą i wykorzystują go politycy wszystkich opcji, a nawet wszyscy organizatorzy świata społecznego. W miarę chłodna, w miarę racjonalna analiza jego istoty powinna doprowadzić nas do konstatacji podobnej do tej, jaką kiedyś zaprezentował V. Pareto, dla którego samo twierdzenie o równości ludzi jest tak absurdalne, że nawet nie zasługuje na to, by je obalać, „natomiast subiektywna idea równości wywiera potężny wpływ na zmiany, jakim ulega społeczeństwo" ${ }^{48}$. A jeśli tak jest, że równości jako zasady domagają się ci, którzy się jej boją - jak widział to M. Scheler - to możemy uznać, że ten mit jest tak wieczny jak strach ${ }^{49}$. Podobnie można interpretować wolność i sprawiedliwość, nie dające się bronić przy pomocy racjonalnych argumentów, a każdy $\mathrm{z}$ nas filtruje te obrazy $\mathrm{w}$ ramach rzeczywistości widzianej przez pryzmat swojej kultury i swojego świata mitycznego, przywołując do tego swoje doświadczenia.

Wyobraźmy sobie, że aspirujący do władzy, demokratyczny polityk podejmuje próbę podważenia mitu równości, twierdząc choćby, że nierówności społeczne są stanem naturalnym (a znamy takich polityków z polskiego podwórka). Zderzyłby się wówczas z wielkim archetypem mitycznym zrytualizowanym przez wieki i byłby z góry skazany nie tylko na klęskę, ale i na potępienie społeczne. Równość, o której każdy wie, że jest nieosiągalna, jest tylko marzeniem i to marzeniem o konotacjach materialnych.

Przeciętny człowiek, pełen naturalnej zawiści, pragnie, by wszyscy spełnili się w świecie materialnym tak samo jak i on i taka równość

48 V. Pareto, Uczucia i działania. Fragmenty socjologiczne, Warszawa 1994, s. 83.

${ }^{49}$ M. Scheler, Resentyment a moralność, Warszawa 1977, s. 173. 
byłaby dlań satysfakcjonująca, a wiemy skądinąd, że argument o podobnych żołądkach jest uniwersalny. Nie chce równości w spełnieniu duchowym, tu z łatwością godzi się na to, że są ludzie od niego mądrzejsi i bardziej utalentowani, ale tej pierwszej będzie bronił zaciekle, traktując swoje prawo do równości niezwykle poważnie. Równość jest częścią jego esencji, jego przestrzeni wiary, a praktyka potwierdza sugestie, że tradycyjne mityczne wzory nie dają się eliminować bez trudu - zauważał amerykański badacz - i by je choć trochę nadkruszyć, potrzebny jest ogromny, rozłożony na lata, a nawet generacje, wysiłek ${ }^{50}$. Jest to jednak możliwe, czego dowodzi amerykańska praktyka, w której wszyscy są równi, ale w szansach, odpowiedzialności i jeśli nie wykorzystują szans, są mniej równi. Godzą się z tym obywatele i Amerykanie raczej nie są w stanie zrozumieć wielu uroszczeń europejskich egalitarystów, swoiście zresztą niekonsekwentnych. Być może także dlatego udało się im uniknąć wielu paroksyzmów społecznych, jakie bywały codziennością starej Europy. Ale mit takiej właśnie równości rytualizowano od początków istnienia kolonii, przenosząc go do prawa i odstępstwo albo próba zakwestionowania jego istoty jest traktowana w Ameryce niemal jak świętokradztwo i trudno nam to zrozumieć, gdyż polski mit równości jest bezwzględny, interpretowany w utopijnym duchu równości doskonałej. Za oceanem zaś spełniono warunek dobrego wkomponowania go w przestrzeń mityczną przyznawał badacz zauważający, że to rzutuje na charakter amerykańskiej formy demokracji51.

Fundamenty mityczne zdają się mocne, tak mocne, że niekiedy rytualizacja, symbolizacja wielu mitów ma charakter przypadkowy, nie całkiem świadomy, co możemy zauważyć choćby w interpretacjach tzw. sprawiedliwości społecznej, prawa stanowionego, czy też w sugestiach o służebności władzy wobec obywateli. Ale istotne jest to, czy mity-archetypy są rytualizowane stale, konsekwentnie, a jeśli są, i jeśli są akceptowane przez społeczność, wówczas pozostają trwałymi

\footnotetext{
${ }^{50}$ R. N. Bellah, Beyond Belief, California University 1991, s. 103.

51 O. Patterson, The American Democracy, New York 1993, s. 2.
} 
wzorami ładu, których nie da się wykorzenić ani łatwo, ani szybko. Takimi były w społeczności, z której wyrosło społeczeństwo uważające się za jedynego i prawdziwego depozytariusza treści i form demokracji.

Twórcy nowych form demokracji w znaczącej mierze przyczynili się do stałego wzrostu partycypacji wyznawców w życiu politycznym, rozszerzania tych form na obywateli płci obojga, także zwierzęta, choć warto pamiętać o tym, że demokracja miała charakter mityczny zanim zniesiono statusy majątkowe dla posiadaczy czynnego i biernego prawa wyborczego. Demokracja w jej treściach i formach spełniała podwójną rolę, była unifikującą wizją spełnienia wartości idealnych i, z drugiej strony, tworzyła nowe formy samoorganizacji społeczeństwa, umożliwiała zbawienie $\mathrm{w}$ doczesności. Rozwiązaniem, jakie uznano za optymalne, miał być system przedstawicielski, kreujący wolę zbiorowości, czyli partie polityczne. One, reprezentujące społeczność, orientując się na kompromis, muszą artykułować jej interesy i stale walczyć o to, by demokracja nie stała się tyranią większości, o co obawiał się nie tylko J.S. Mill i obawiał się raczej zasadnie, bo i dziś zbyt często słyszymy argumentację typu: „wolą większości jest..... A ta większość jest jedną z iluzji nowoczesności.

Wyborcy swoje iluzje uczestnictwa podtrzymują, przejmując opinie, naśladując zachowania innych, zwłaszcza wtedy, gdy ich położenie jest niepewne. Są współuczestnikami „demokracji imitacyjnej” tworu opieranego na fundamentach mitycznych. Takim tworem zdaje się właśnie polska demokracja przełomu wieków, gdy tzw. zdyscyplinowani wyborcy rekrutują się właśnie spośród tych, dla których mityczne ideologie i ich emanacje są tworami racjonalnymi. Oni wierzą w mit racjonalnego wyborcy, taki mit jest przyjmowany tak łatwo, bo ułatwia identyfikację polityczną ${ }^{52}$. Wyborcy racjonalizujący zaś, dostrzegając mityczny charakter "programów” politycznych, deklarują brak wiary przez nieuczestniczenie w wyborach. Oni nie wierzą już

${ }^{52}$ K. S. Johnson-Cartee, S.A. Copeland, Manipulation of the American Voter, Westport 1997, s. 76. 
w mit altruizmu polityków, a taka wiara, sprzężona z emocjami, jest podstawą aktywizmu politycznego ${ }^{53}$. I to raczej nie te grupy przesądzają o erozji demokracji, o co były tak często oskarżane w III RP. Nie ich winą jest to, że nie chcą legitymizować formy bez treści, a takich treści nie zauważają tam, gdzie być powinny, czyli w kodeksach prawa. Dziś w Polsce mamy do czynienia z syndromem „pustego płaszcza”, $\mathrm{z}$ tym, co jeden $\mathrm{z}$ autorów zasadnie nazwał partiokracją, uznając ją za nowotworową chorobę demokracji ${ }^{54}$. Tak ostre tony nie są rzadkością w naukach społecznych, ale pozostaje wciąż niedosyt, bo poza tak zdecydowanymi diagnozami nie spotykamy prób proponowania skutecznych terapii.

Polscy wyborcy i wyznawcy zarazem są na swój sposób specyficzni, ale i bliscy regułom. Potwierdzają racje teoretyka, że partycypacja w demokracji jest niezwykle trudna, jeżeli społeczność jest pogrążona w anomii i niedostatku55. Biedni i niewykształceni, czujący wykluczenie, nie chcą wybierać jakby na przekór zdrowemu rozsądkowi. Przecież dobry wybór mógłby być początkiem zbawienia, a tymczasem oni wykazują nie tyle rezerwę, co niechęć w uczestnictwie w wyborach. Tak ogromny dystans między nimi a formą władzy zdaje się pochodzić znowu z regulacji idealistycznej, z pokładów wiary. $\mathrm{Ci}$ wyborcy po prostu nie wierzą w zbawienie przez nią i odnajdują setki przesłanek, zwłaszcza w zachowaniach polityków, potwierdzających takie ich tezy. Jakimś tego potwierdzeniem jest poszukiwanie jednostkowego sotera. Badania socjologów potwierdzają nową wiarę Polaków w mityzowaną demokrację, ale manifestując taką wiarę respondenci uważali zarazem, że krajowi jest potrzebny silny przywódca, który zaprowadzi w kraju porządek. To nie sprzeczność, ale postać wiary w siłę zbawczą, jaka zdaje się gwarantować lepsze wa-

53 S. Kelman, Why Public Ideas Matter, [w:] The Power of Public Ideas, R.B. Reicha (red.), Harvard 1990, s. 47.

54 J. Muszyński, Polskie Państwo Partyjne, Warszawa 2002, s. 11.

55 D. Held, Models of Democracy, Cambridge 1987, s. 271. 
runki życia.. Paradoksem było jedynie to, że owa silna jednostka nie mogła mieć prawa do ograniczania przywilejów demokracji.

Próbując antycypować jej rozwój, jesteśmy raczej bezradni, pewni tylko tego, że jej treści wymuszają nowe formy i z pewnością te, jakie pojawiają się $\mathrm{w}$ naszym czasie, nie są ostatnimi nowościami nadającymi tym formom nieco karykaturalne oblicza. Taką formą, mającą potwierdzać żywotność demokracji i podkreślać jej swoiście rozumianą postępowość, jest polityczna poprawność, ten rodzaj „odwróconego maccartyzmu"56. Ale to nie tylko ta, czasami wręcz karykaturalna, „poprawność” przypominająca wysublimowane konwenanse dworskie XVII i XVII wieku, a także poszukiwania wszelkich możliwości poszerzania ram wolności, sprawiedliwości w krajach, gdzie demokracja jest fetyszem, formą dla formy. Ona musi się potwierdzać, ale niekiedy jej nowe formy czynią ją samą czymś sobie przeciwnym i osiąga to już nie granice antynomii, a aporii.

Demokracja form z pozoru pozwala się spełniać materialnie, bo rzekomo jest symbiontem kapitalizmu, co jest tylko mityzacją, ale musi ulegać dynamice treści, bo tęsknoty za wolnością, równością i sprawiedliwością przybierają coraz to nowe formy i muszą być zaspokajane nie przy pomocy placebo. A tak dzieje się w demokracjach form i w zgiełku postnowoczesności szuka się nowych poziomów równości dla dzieci, a nawet małp naczelnych (Hiszpania), jakby powinności państwa i społeczeństwa wobec dzieci i małp nie wystarczały. Pojawiły się także głosy, by radykalnie obniżać prawo głosowania, przyznając je dzieciom. Argumenty zdają się nawet racjonalne, bo przecież wybierając polityków dzieci, wybierają swoją przyszłość. Ale mając na uwadze stosunek tych polityków do przyszłości, a także sposoby specjalistów od marketingu politycznego, moglibyśmy obawiać się o to, że byłyby to wybory najgorsze. Elektorat dziecięcy byłby łatwiejszy w manipulacjach. Dzieci mają więcej wiary niż dorośli, a ich spełnienie zdaje się prostsze i... tańsze. Zamiast kiełbasy wyborczej starczyłyby cukierki.

56 P. Ricoeur, Krytyka i przekonanie, Warszawa 2003, s. 84. 
W naszym czasie demokracja przestaje być formą zbawienia właśnie za sprawą tych, którzy tworzą jej formy - polityków. Oni tworzą wiele wizji zbawiania, konstytuują niespełnione nadzieje, a nie spełniając ich, odzierają społeczności z tego, co zwie się złudzeniami. Prawie zawsze - zauważał teoretyk propagandy - stopniujący technikę schlebiania obiecują przyszłość, której nie są w stanie zapewnić. Dla przekonania i zdobycia poparcia społecznego rysowane są obrazy przyszłych sukcesów, zwycięstw, osiągnięć gospodarczych, powszechnego bogactwa. Wszystko to znajdzie się $\mathrm{w}$ zasięgu ręki, jeśli społeczeństwo podporządkuje się57. Dziś polityka stała się domeną jednostek kratycznych (władczych) myślących przede wszystkim o samozbawieniu. Zdaje się, że to politycy najprędzej przesiąkli postmodernistycznymi "innowacjami” i to za ich sprawą polityka stała się farsą. Po części dlatego, że w takim czasie poznali granice własnej niekompetencji i zrezygnowali z prób prawdziwego rządzenia, ufając w sprawność aparatów biurokratycznych, a wtedy, kiedy one zdają się zawodzić, po prostu je rozbudowują.

Nieprzystawalność demokracji do naszego czasu to jeden z megatrendów J. Naisbitta ${ }^{58}$. Obserwując ten nasz czas, można stwierdzić, że chyba jednak odwracanie się od demokracji jest trendem, jaki można ekstrapolować w przyszłość. Coraz częściej pojawiają się pytania o przyczyny i tu spotykamy wiele prób, poczynając od tych S. Huntingtona, poszukującego źródeł regresu w braku identyfikacji elit z masa$\mathrm{mi}$, załamaniach gospodarczych, czyli braku bogactwa ${ }^{59}$. Wiele $\mathrm{z}$ takich przesłanek spotykaliśmy już w poprzednich rozdziałach i poza tym teoretykiem możemy przywołać społeczną inercję sparaliżowanych sytą gnuśnością społeczeństw, przekonanych o trwałości systemu. Naszym zdaniem takich przyczyn powinniśmy doszukiwać się także w braku treści w formach, ale także w osłabieniu wiary w ogóle. Być może to ta słabość sprawia, że rządy demokratyczne muszą bezu-

\footnotetext{
57 0. Thompson, Historia propagandy, Warszawa 2001, s. 449.

58 J. Naisbitt, Megatrendy, Poznań 1997, s. 18

59 S. P. Huntington, Trzecia fala demokratyzacji, Warszawa 1995, s. 289.
} 
stannie potwierdzać swą wierność wolności, równości i poszerzać ich granice, a nie bardzo wiedzą, jak to robić. Muszą sprawiać, że wielkie masy ludzkie wiedzą, co robią i dlaczego to robią, ale nie wtedy, kiedy wydaje się im, że wiedzą, co robią - twierdził Chomsky ${ }^{60}$, ale zdaje się, że $\mathrm{w}$ takim sądzie jest wiele przesady. One muszą sprawiać, by te wielkie masy robiły to, co rządzący chcą, by zrobiły. Samoświadomość mas nie jest i nie będzie ich celem

Ale o słabości form przesądzają ci, którzy je tworzą, czyli my wszyscy, mający teoretyczne moce sprawcze, teoretyczną moc wymuszania na twórcach demokracji znaczących korekt, a prawdziwymi twórcami jej dawnych i dzisiejszych form są, jak przed laty, oligarchowie, którzy, według E. Todda, są właściwie zmuszeni do radykalnych przekształceń systemowych ${ }^{61}$. Z jednej strony demokratyczne rządy nie satysfakcjonują tych, którzy mają pieniądze, a z drugiej zrelatywizowane klimaty ponowoczesności sprawiają, że społeczeństwa nie tyle nie wchodzą w dorosłość ${ }^{2}$, co gubią się w gąszczu ideologicznych niedomówień, nie są już tak zewnątrzsterowne. Jeszcze wierzą, ale bezkrytyczna wiara w demokrację przyzwala na tolerowanie złych wyborów, ale także kruszy tą wiarę.

W naszej epoce uzbrojonej globalizacji marzenia o demokracji są już definitywnie przegrane - to zdanie twórców równie głośnego, co kontrowersyjnego „Imperium” 63. Nie tylko oni są takiego zdania. Podziela je wielu sceptycznie, ale i prospektywnie nastawionych autorów. „Dla nas - pisał D. Korten - którzy dorastali wierząc, że kapitalizm jest fundamentem demokracji i wolnego rynku, koszmarnym przebudzeniem było uświadomienie sobie, że pod rządami kapitalizmu demokracja jest na sprzedaż, a rynek planowany przez megakor-

60 N. Chomsky, Language and Politics, London 2004, s. 109.

${ }^{61}$ E. Todd, Schyłek imperium. Rozważania o rozkładzie systemu amerykańskiego, Warszawa 2003, s. 23.

62 P. Virillo, Bomba informacyjna, Warszawa 2006, s. 90.

${ }^{63}$ M. Hardt, A. Negri, Multitude. War and Bureaucracy in the Age of Empire, New York 2004, s. XI. 
poracje, potężniejsze niż większość państw"64. Nie jest to zdanie podzielane przez analityków globalizacji. Oni jednak dostrzegają szanse transnarodowej demokracji, uważając, że przydałaby większą wagę wielu instytucjom międzynarodowym ${ }^{65}$.

\section{Bibliografia:}

Baudrillard J., Procesja symulakrów, [w:] Nowe media w komunikacji społecznej $w X X$ wieku, M. Hopfinger (red.), Warszawa 2002.

Baudrillard J., Społeczeństwo konsumpcyjne, Warszawa 2004.

Bauman Z., Wolność, Kraków 1995.

Bell D., The Cultural Contradiction of Capitalism, London 1979.

Bellah R.N., Beyond Belief, California University 1991.

Boaz D., Libertarianizm, Poznań 2005.

Brighthouse H., Sprawiedliwość, Warszawa 2007.

Chomsky N., Language and Politics, London 2004.

Chomsky N., Media Control, New York 2002.

Conquest R., Uwagi o spustoszonym stuleciu, Warszawa 2001.

Conrad J., Człowiek, rasa, kultura, Warszawa 1971.

Dijk van T.A., Elite Discourse and Racism, Newbury Park 1993.

Friedman M., Capitalism and Freedom, Chicago 1982.

Ginsberg B., T.J. Lowi T.J., M. Weir M., We the People, New York 1997.

Goldfarb J.C., The Cynical Society. The Culture of Politics and the Politics of Culture in American Life, Chicago 1991.

Hamel G., C.K., Prahald Competing for the Future, Cambridge 1994.

Handy Ch., Wiek paradoksu, Warszawa 1996.

Hardt M., Negri A., Multitude. War and Bureaucracy in the Age of Empire, New York 2004.

Harman E.S., Chesnay R.W., The Global Media. The New Mission of Corporate Capitalism, London 1999.

Held D., Models of Democracy, Cambridge 1987.

64 D. C. Korten, Świat po kapitalizmie, Łódź 2002, s. 11.

65 T. D. Zweifel, International Organizations and Democracy. Accountability, Politics and Power, London 2006, s. 175. 
Andrzej Sepkowski - Zbawienie w demokracji

Herring J., The Politics of Democracy. American Parties in Action, New York 1968.

Huntington S.P., Trzecia fala demokratyzacji, Warszawa 1995.

Johnson-Cartee K.S., S.A. Copeland, Manipulation of the American Voter, Westport 1997.

Kelman S., Why Public Ideas Matter [w:] The Power of Public Ideas, R.B. Reicha (red.) , Harvard 1990.

Kilanowski M., Individual and Community, [w:] Deconstruction and Reconstruction, J. Ryder, M. Wilkanowski (red.), Amsterdam 2004.

Mc Coil H.W., The History of Liberty, New York 1965.

Muszyński J., Polskie Państwo Partyjne, Warszawa 2002.

Naisbitt J., Megatrendy, Poznań 1997.

Pareto V., Uczucia i działania. Fragmenty socjologiczne, Warszawa 1994.

Patterson J.T., America's Struggle Against Poverty, Harvard 1994.

Patterson 0., The American Democracy, New York 1993.

Possenti V., Religia i życie publiczne. Chrześcijaństwo $w$ dobie ponowożytnej, Warszawa 2005.

R.A. Dahl R.A., Dillemas of Pluralist Democracy, London 1982.

Ricoeur P., Krytyka i przekonanie, Warszawa 2003.

Ryn C.G., Democracy and the Ethical Life. A Philosophy of Politics and Community, London 1979.

Scheler M., Resentyment a moralność, Warszawa 1977.

Sorensen G., Democracy and Democratization. Dilemmas in World Politics, Boulder 1993.

Staniszkis J., Władza globalizacji, Warszawa 2003.

Thompson J.B., Media i nowoczesność. Społeczna teoria mediów, Wrocław 2001.

Thompson 0., Historia propagandy, Warszawa 2001.

Thurow L., Przyszłość kapitalizmu, Wrocław 1999.

Todd E., Schyłek imperium. Rozważania o rozkładzie systemu amerykańskiego, Warszawa 2003.

Virillo P., Bomba informacyjna, Warszawa 2006.

Zadencki J., Wobec despotyzmu wolności, Kraków 1995. 